\title{
Expansion and Consolidation of Islam in Iran to the End of Qajar Period
}

\author{
Ashaq Hussain, \\ University of Kashmir, India \\ Ghulam Nabi Khaki \\ University of Kashmir, India
}

\section{INTRODUCTION}

Dozy says in his excellent work on Islam, "During the first half of the seventh century, everything followed its accustomed course in the Byzantine as in the Persian empire. These two cities continued always to dispute the possession of western Asia; there were, to all outward appearance, flourishing; the taxes which poured into the treasuries of their kings reached considerable sums, and the magnificence, as well as in the luxury of their capitals had become proverbial. But all this was in appearance, for a secret disease consumed both empires; they were burdened by a crushing despotism; on either hand the history of the dynasties formed a concatenation of horrors, that of state a series of persecutions born of dissentions in religious matters. At this juncture it was that, all of a sudden, there emerged from deserts hardly known and appeared on the scene of the world a new people, hitherto divided into innumerable nomad tribes, who, for the most part, had been at war, with one another, now for the first time united. It was this people, passionately attached to liberty, simple in their food and dress, noble and hospitable, gay and witty, but at the same time proud, irascible, and once their passions were aroused, vindictive, irreconcilable and cruel, who overthrew in an instant the venerable but rotten Empire of the Persians, snatched from the successors of Constantine their fairest provinces, trampled their feet a Germanic kingdom but lately founded, and menaced the rest of Europe, while at the same time, at the other end of the world, its victorious armies penetrated to the Himalayas. Yet it was not like so many other conquering peoples, for it preached at the same time a new religion. In opposition to the dualism of the Persians and a degenerate Christianity, it announced a pure monotheism which was accepted by 
millions of men, and which, even in our own time, constitutes the religion of a tenth part of the human race"

\section{ISLAM IN IRAN}

After the Treaty of Hudaybiyyah in 628 C.E, Prophet Muhammad (SAW) sent embassies to the foreign powers inviting them to accept Islam. These letters were carried by ambassadors to the Kisra of Iran, the Byzantine Emperor, the ruler of Egypt, Negus of Abyssinia, the king of Ghassinids and the chief of yammama. However, the embassy to Abyssinia proved successful, and the Negus accepted Islam. Maquqas of Egypt sent valuable gifts to the Holy Prophet (SAW). The Emperor of Byzantium regretted his inability to accept Islam, but treated the embassy with due courtesy. The chief of yammama stipulated that he would accept Islam if the Holy Prophet shared his prophethood with him. The Kisra of Iran tore the letter of the Holy Prophet (SAW) in indignation and directed his agents in Yemen to arrest the Holy Prophet (SAW) and send him to his court.

The triumph of the Muslim Arabs over the Sasasian Empire was due to two main causes. First, there was the exhaustion of the Sasanian power by the long-drawnout struggle with the Byzantine Empire. Secondly, the Arabs were united as they had never been before by their new faith. The Arab conquest resulted, inter alia, in the disappearance of the Pahlavi language and, except in the more remote areas, of the Zoroastrian religion. Furthermore, the rigid monarchial system of the Sasanians was replaced by a democratic form of government under the Caliphate.

After the demise of Prophet Muhammad (SAW), Abu Bakr was appointed Caliph and political successor at Medina. On becoming the Khalifah he was confronted with many problems. The appearance of the false Prophets, the apostasy movement among the various tribes of Arabia and the refusal of a strong section of people to pay Zakat were a challenge to the newly established state. [1] Abu Bakr seriously turns his attention to the conquest and conversion of non-Arabian lands. The first major encounter between the Arabs and Iran occurred during the reign of the first caliph, Abu Bakr (632-634). The frontiers of Persia were the most formidable to the Arabs, and those which inspired in their minds the greatest respect and fear, so that they were loath to attack them, but rather avoided them out of respect for the state of the Persian kings, and because of what was generally believed as to their power to subdue other nations. And thus it continued until the latter days of Abu Bakr, when there arouse a man of companions named al-Muthana son of Haritha, who incited the people to give battle to the Persians, making light of the matter and inspiring them with courage therein. So a number of them responded to his appeal, 
and men remembered what the apostle of God had promised them in respect to the taking possession of the treasuries of the Persian kings. But naught was affected in the matter during the Caliphate of Abu Bakr.

After Abu Bakr, Umar ascended the throne and the first thing that Umar did was to strengthen the Iraq front. His brilliant conquests and benevolent administration inaugurated a new era in the history of the world. Under his rule Islamic Empire expanded with almost miraculous speed, and it is fair to say that it was Umar who, after the Prophet, was most influential in molding the Islamic state, and in determining its nature. [2] In his times various countries were conquered, spoil multiplied, the treasures of the Persian king and the Roman Emperor were poured in streams before his troops, and nevertheless he himself manifested a degree of abstemiousness and moderation at no other time attained. [3] Khalid b.Walid was engaged in Syria and against the Byzantium while, moreover, 'Umar was dissatisfied with him, though he was unable, in spite of the new caliph's urging, to muster sufficient to fight the Iranians, Abu Ubaida Thaqafi had no alternative but to go to Mesopotamia, where the caliph placed Muthanna under his command. Abu Ubaida encountered the Persian force, commanded by Bahman Jaduya, at a place near the present site of Kufa on the banks of the Euphrates, the Arabs being on the west bank in a spot called Mirwaha and the Iranians on the opposite bank. As the two places were linked by a bridge, the battle which followed is known as the 'Battle of Bridge'. However, Abu Ubayda against the advice of Muthana crossed the river and gave battle to the Persians. The battle was lost by the Muslims and Abu Ubayda lost his life. [4] However, later Persian forces were defeated by Muthana in the Battle of Buwaib. However, the Arabs regained upper hand and their territorial expansion continued. Their victory in the second battle of Yarmuk in August 636 completed the conquest of Syria and the Caliph sent part of the Syrian army to the Mesopotamian front, their ranks swelled by large numbers of fresh volunteers. Umar assigned the task of commanding the army to its able General Sa'd b.Waqqas. The Iranians moved southwards until they were close to al-Qadisiya, a small fortified town some $30 \mathrm{~km}$ from, Kufa, and subsequent events took place on the bank of the 'Atiq channel. To begin with, the Iranian General first tried the negotiations that were as protracted as they were futile, and the Arabs soon found themselves confronting a huge Persian army with troops drawn from every corner of the empire and commanded by its foremost generals. Among the troops were fearsome war elephants that the Persian commander brought with him for the sole purpose of vanquishing the Muslims. Within three months, Sa'd defeated the Persian army in the Battle of Qadisiyah, effectively ending Sassanid rule west of Persia proper. The battle of Qadisiyah was a battle with a great historic importance as it completely broke down the strength of Persia and secured for 
Islam a footing ground in Persia. [5] According to Zarrinkub: "On entering the palace of Khusrau, Sa'd had performed an eight rak'at prayer for his victory and, because of its appropriateness in recalling the fate of those who reject God, recited the Qur'anic verse (44:25-27) which begins with 'How many gardens and springs have they left'. He made a mosque in the citadel and the four-hundred year old capital of the Sasanians became for a time the camping ground of this Muslim general".

The conquest of Khuzestan then began. The Arabs were led by Abu Musa Ash'ari, the future governor of Basra. One after another, the towns and strongholds of Khuzestan fell to the Arabs, including the provincial capital of Ahvaz. From Ahvaz, he occupied himself in raiding the Maisan district, which was held by the Basra Arabs. The next immediate conquest was battle of Nihavend, Umar mobilized an impressive number of troops, whom came from Syria; Nu'man b.Amr b.Muqarrin was appointed commander-in-chief. During the fierce fighting that resulted, both sides incurred heavy losses, but the scales eventually tipped in the Arab's favor. Although, their commander-in-chief was killed, the Arabs continued to attack and the Iranian army was routed, part of its seeking refuge in the town and the neighboring fortress. The Iranians then abandoned the fortress, emerged on to the battlefield and continued fighting. They were utterly defeated. The ruler of Nihavend managed to conclude a charter of immunity for the population of the town, but the Arabs seized great quantities of booty, including the treasuries of the fire temple. The Battle of Nihavend was one of the most decisive battles in Islamic history. The battle proved to be the key to Persia. According to Al-Tabari, 'from that day on, there was no further unity among them (Persians) and the people of the individual provinces fought their own countries on their own territory. Isfahan was taken in 643 and 644, and Ray was captured at the same time. The Arabs next step was to subjugate Iran's Northern provinces. They also took possession of Persia and Kerman.

Seistan was believed to be the largest province of the Sassanid Empire. In the south it bordered with Kerman and in the north with Khurasan. Seistan in ancient times was one of the remote eastern provinces of the Sasanian Empire. 'Asim marched and Muslim troops already present in Fars, entered Seistan. The Persian showed no resistance and cities after cities were conquered. The conquest of Azerbaijan began after Nihavend and was undertaken by the same warriors for the faith. Among them Hudhaifa b.al-Yaman, who raided Ardabil, the centre of the province and seat of the governor. After a stiff resistance this city submitted and accepted the imposition of the jizya. 
Khurasan was the second largest province of the Sassanid Empire. Ahnaf ib Qa'is marched from Kufa and selected a short frequented route via Rey and Nishapur. Herat was captured, and the whole of southern Khurasan fell into the hands of Muslims. Continuing eastwards, he reached and captured Balkh. Khurasan was subdued but the local population persistently rebelled against the Arabs. Caliph Umar was assassinated in November 644 by a Persian slave. The assassination is often seen by various historians as a Persian conspiracy against Umar. [6] Hormuzan is said to have masterminded this plot.

Caliph Uthman ibn Affan (644-656) succeeded Umar. During his reign almost the whole of the former Sassanid Empire's territory rebelled from time to time until 651, until the last Sassanid emperor was assassinated near Marv ending the Sassanid dynasty and Persian resistance to the Muslims. Caliph Uthman therefore had to send several military expeditions to crush the rebellions and recapture Persia and their vassal states. The Empire expanded beyond the borders of the Sassanid Empire in Transoxiana, Baluchistan and the Caucasus. The main rebellion was in the Persian provinces of Armenia, Azerbaijan, Fars, Seistan (in 649), Tabaristan, Khurasan (651), and Makran (650). [7]

Yazdegerd, after being defeated at the Battle of Oxus River in $644 \mathrm{CE} / \mathrm{AD}$, was unable to raise another army and became a hunted fugitive. Following the battle he fled to Central Asia to the court of the Khan of Farghana. From there Yazdegerd went to China. Nevertheless Yazdegerd III kept on returning to Persia to exert his influence over the notables and chiefs of Persia. He thus remained a motivating force behind the Persian rebellion. During Caliph Uthman's reign Yazdegerd III came back to Khurasan rebelled against the Caliphate. Abdullah ibn Aamir crushed the rebellion and defeated Yazdegerd's forces. He fled from one district to another until a local miller killed him for his purse at Merv in 651. For many decades to come, this was the easternmost limit of Muslim rule.

During the reign of the Umayyad dynasty, the Arab conquerors imposed Arabic as the primary language of the subject peoples throughout their empire. Up to the time of Abdul Malik, the accounts were still written entirely in Persian notation. Hajjaj, who was not happy about the mawali predominance and prevalence of the Persian language in the divan, took measures to have its language changed into Arabic, thereby making the supervision of the affairs of non-Arabs by Arabs more extended. The person who accomplished this for Hajjaj was himself an Iranian, one of the clients of the Bani Tamim named Salih b. 'Abd al-Rahman, Seistani. He worked in the divan with Zadan Farrukh b. Piruz. When the latter was killed in the course of the insurrection of Ibn Ash'ath, Hajjaj ordered Salih to effect the change into Arabic, in spite of the fact that Zadan's son, Mardan shah, endeavored to 
obstruct the innovation. Abdul Malik also established a mint in Damascus to produce coins with Arabic inscriptions, and Hajjaj also struck a new coinage to replace the old. Until this time the currency of Iraq and Iran had been of the ancient pattern. In spite of the change from Persian to Arabic notation in the divan and the new coinage, contrary to what Mardanshah had foreseen, the Persian vernacular did not disappear, while the governors, who succeeded Hajjaj, though themselves Arabs, were forced increasingly to take advantage of the presence of mawali in the divan. [8] Umayyad dynasty promoted factionalism by setting up Dhimmah to collect taxes from Dhimmis to benefit the Arab Muslim community and by discouraging the conversion. Their attempted reforms, however, began too late to silence the numerous discontented whose patience had been exhausted by years of the injustice of Arab intendants and their Iranian tax gatherers. Moreover, Umayyads seriously vexed the Dhimmis, upon whom the tax burden fell heaviest. Finally, internal differences among the Arabs gave this last but no opportunity to continue his ameliorative efforts; it was in the midst of his various difficulties that the secret 'Abbasid propaganda burst into the open and began to bear fruit. [9]

Dozy writes "The ascendancy of the Persians over the Arabs, that is to say of the conquered over the victors, had already for a long while been in course of preparation; it became complete when the Abbasids, who owed their elevation to the Persians, ascended the throne. These princes made it a rule to be on their guard against the Arabs, and to put their trust only in foreigners, Persians, especially those of Khurasan, with whom, therefore, they had to make friends. The most distinguished personages at court were consequently Persians. The famous Barmecides were descended from a Persian noble who had been superintendent of the fire-temple at Balkh. Afshin, the all-powerful favorite of the Caliph alMu'tasim, was a scion of the princes of Urushna in Transoxiana. The Arabs, it is true, murmured, and endeavored to regain their ancient preponderance. The war which broke out between the two brother's al-Amin and al-Ma'mun, the sons of Harun-al Rashid, was in its essence merely the renewal of the war waged between the Arab and Persian nationalities for the supremacy. Bu the Arabs again experienced a check; again, cost them what it might, they had to recognize the supremacy of Persia; again they were compelled to watch as passive spectators a change of government dependent on the defeat of one of these races by the other and resulting from it. The democratic point of view of the Arabs was, indeed, replaced by the despotic ideas of the Persian". [10] The Abbasid period is characterized by the ascendancy of Persian influence, and is therefore well defined, and reached its culminating point in the splendid reign of al-Ma'mun, whose mother and wife were both Persians, and whose ministers, favorites, and personal characteristics were, for the most part, Persian also. Persian influence increased at the court of the Caliphs, and reached its Zenith under al-Hadi, Harun al-Rashid, 
and al-Ma'mun. Most of the ministers of the last were Persians or of Persian extraction. In Baghdad Persian fashions continued to enjoy an increasing ascendancy. The old Persian festivals of the Nauroz, Mihrgan, and Ram were celebrated. Persian raiment was the official court dress, and the tall, black, conical Persian hats were prescribed by the second Abbasid Caliph. At the court the customs of the Sasanian kings were imitated, and garments decorated with golden inscriptions were introduced, which it was the exclusive privilege of the ruler to bestow. A coin of the Caliph al-Mutawakkil shows us this Prince actually clothed in true Persian fashion. The Abbasids owing their rise entirely to Persian influence, it was only natural that Persian counsels should prevail, and we accordingly find a minister of Persian extraction at the head of affairs, and the Caliphate carried on by almost precisely the same machinery as that by which the Empire of the Sasanians was governed. [11]

\section{ISLAMIZATION OF IRAN}

During the Umayyad period, only $10 \%$ converted to Islam as compared to Abbasid revolution, in which Iranian converts played a major role, and made significant Iranian influences. [12] Vambery states: 'Islam was whole heartedly accepted by Zoroastrians, and Muslims did not face any such difficulty to preach Islam, as there were many similarities between the faiths. Muslim leaders made every possible effort to win the hearts of those who were new entrants and allowed the Quran to be recited in Persian instead of Arabic so that it would be intelligible to all'. [13] Although Persians made utmost efforts to protect and revive their language and culture, and adopted the religion of the Arabs i:e Islam. [14] In the $9^{\text {th }}$ and $10^{\text {th }}$ centuries, a movement started called Shu'ubiyyah in response to the privileged status of Arabs. It was basically a movement for preserving Persian culture and protecting Persian identity, but the primary aim of the movement was the survival of the Persian language.

In the $9^{\text {th }}$ century $\mathrm{AD}$, when the Abbasid Caliphate had lost some of its power and influence in outlying parts of its realm, the Persian spirit showed signs of resurgence by the appearance of local dynasties such as that of the Saffarids in 867 , the Samanids in 874 and the Buyids in 932. In the meantime simultaneously, the Persian language began to emerge, but in a new guise, as it was enriched by the inclusion of many Arabic words and it used the Arabic script in place of the cumbrous and difficult Pahlavi system of writing. During this period, at Bukhara the enlightened Samanid rulers patronized men of great learning such as the famous Philosopher Abu 'Ali ibn Sina (Avicenna). Moreover, modern Persian 
literature may be said to have originated there, with the emergence of the poets Rudaqi and Daqiqi. So many of this later period which are to this day standard texts in Muslim Madrassas, both Sunni and Shi'i, works of such men as Ghazzali, Fakhr al-Din al-Razi, Zamakhshari, Baidawi, Nar al-Din al- Tusi, Taftazani, Sayyid Sharif al-Jurjani and Jalal al-Din al-Dawani, to cite just a few of the better known names, are connected with the Persian world. Ghazzali alone would be sufficient to underline the significance of the contribution of Persia to Islamic civilization, in the same way that a figure as he is also an outstanding example of the result of the downporuing of the grace of the Qur'anic revelation upon the soil of Persia. [15]

In 961 a Turkish governor of the Samanids, Alptgin, conquered Ghazana (in present-day Afghanistan) and established a dynasty, the Ghaznavids that lasted to 1186. [16] Mahmud was embarked on his amazing career of conquests. He was not only a great warrior and conqueror but also a great patron of learning and scholasticism. In the course of conquests, Mahmud brought home libraries from Rey, Isfahan and India. According to Tarikh i-Daulat Shahi: '400 poets and scholars would regularly attend the court of Mahmud to glorify and preserve sultan's warfare's". By and large, during the Ghaznavid period, state administrative structure was greatly influenced by Islam. Renowned works, scholars, academic institutions, patronage of sultans to learned men further excelled the process of knowledge and learning. He patronized was Abu'l Qasim Mansur Firdausi. The Nationale legend find its ultimate development in the celebrated epic of the Shahname, or 'Book of Kings' an immense poem, generally computed at about 60, 000 couplets, composed by Firdausi for sultan Mahmud of Ghazna, and completed, after some forty years of labor, in the year A.D, 1010. [17] Although he began his masterpiece the Shahname (Book of Kings) under the Samanids, he completed it while Mahmud was on the throne. The work has contributed more than any other to the molding of Persian national consciousness: in it Firdausi has preserved for all time the myths, legends and traditions of pre-Islamic Iran. [18] The dynasty assimilated Persian influence in the realms of language and culture..

The Saljuqs, who like the Ghaznavids were Turks, slowly conquered Iran over the course of the 11th century. The reign of Toghril Beg (1037-63), his nephew and successor Alp Arslan (1063-72) and Malik Shah (1072-92), Alp Arslan's son, covered the most brilliant period of Seljuq rule over Persia. Malik Shah, who made Isfahan his capital, adorned it with the magnificent Masjid-I Jami or Friday mosque, and a number of other buildings. The Seljuq era, especially during the reign of Malik Shah, was a great one for literature, science and religion. The famous mystic and theologian Ghazzali was a protégé of Nizam al-Mulk. Another notable figure was Omar Khayyam, the well known mathematician, astronomer 
and Philosopher. Nasir-i Khusrau, the noted traveler and Isma'illi propagandist, was also an eminent figure of that time, but he was not in favor at the court because of his Isma'illi views. After the death of Malik Shah, the decline of the Saljuq Empire began, other dynasties began to step up in its place, including a resurgent Abbasid caliphate and the Khwarizmshahs. The Khwarizmid Empire was a Sunni Muslim dynasty that ruled in Central Asia. Khwarizmshahs became independent in Transoxiana in the north-east and extended their power over most part of Persia. [19]

The Mongol invasion of Iran began in 1219, which brought the massacre, destruction and loss of human lives and material things. During 1220-21 Bukhara, Samarkand, Herat, Tus, and Nishapurwere razed, and the whole populations were slaughtered. Never, it would seem, was Persian nationhood in greater danger of complete destruction than at the time of the Mongol invasion. The famous Arab historian Ibn al-Athir remarks in his annalistic history that for some years he was averse from mentioning this event, deeming it so horrible that he shrank from discussing it. It was, he protested, 'the greatest Catastrophe and most dire calamity' that had ever overtaken mankind. He refers in particular to the great massacres in the cities of north-eastern Persia, in which astronomical numbers of people were slaughtered. The Mongol invasion was disastrous to the Iranians. Everything was destroyed, Islamic scholarship, culture and infrastructure was destroyed as the invaders burned libraries and replaced mosques with Buddhist temples. After Genghis' death, Iran was ruled by several Mongol commanders. Genghiz's grandson, Hulagu Khan, was tasked with expanding the Mongol empire in Iran in 1255. Arriving with an army, he established himself in the region and founded the Ilkhanate, which would rule Iran for the next eighty years. He seized Baghdad in 1258 and put the last Abbasid caliph to death. The palace of the Caliph was ransacked by the Mongols, and all Jewels and other valuable property was captured by them. [20]

The rule of Hulagu's great-grandson, Ghazan Khan (1296-1353) was originally a Buddhist, but a few years before his accession he was converted to Islam. Nauroz, the commander of the Mongol forces in Khurasan, who was a Muslim, was responsible for the conversion to Islam. Ghazan made a remarkable contribution in diverse topics as natural history, medicine, astronomy and chemistry and was also well versed in handicrafts. He promoted learning and established madrasas as he was well read. Under him many Mongols entered into the fold of Islam. Rashid-uddin, the famous historian wrote an account of the reign of Ghazan entitled 'Tarikh$i$-Ghazani. He was a good Muslim and he enforced Shar'iah. [21] 
During the fourteenth century, Central Asia produced another world conqueror, Amir Timur. He was also a Mongol, but Muslim who carried Muslim arms in nonMuslim lands and extended the frontiers of the Muslim world. [22] After established himself in Transoxiana and Turkestan, he invaded Iran in 1382 and conquered. His rule was characterized by its inclusion of Iranians in administrative roles and promotion of arts, architecture and poetry. Persian literature, especially Persian poetry occupied a central place in Timurid period. [23] The Timurid sultans, especially Shah Rukh Mirza and his son Mohammad Taragai Olog Beg, patronized Persian culture. Only in eastern Persia did Timurid rule continue under the cultured and talented Shah Rukh, whose seat of government was at Heart. Under his wise and beneficent rule, and that of his son and successor Ulugh Beg, eastern Persia prospered greatly, and poets, artists, musicians, architects and scholars all flourished, Baisunghar, another son of Shah Rukh, was a great patron of the arts and was himself an artist and calligrapher of note. Among the most important literary works of the Timurid era is the Persian biography of Timur, known as 'Zafarnameh' written by Sharaf ud-Dīn Alī Yazdī, which itself is based on an older 'Zafarnameh' by Nizām al-Dīn Shāmī, the official biographer of Timur during his lifetime. The most famous poet of the Timurid era was Nur-ud-din Jami, the last great medieval Sufi mystic of Persia and one of the greatest in Persian poetry.

Samarqand became the chief city of the world under the Timurids. He modified the city by laboring the best skilled workmen, artisans and designers from all over the world and carried them to Samarqand. However, Timurid control over northeastern Persia did not last long, as Miran shah and his tow sons exhausted their strength in fighting one-another and so made it easy for Qara yosuf, the chief of the Turcoman tribe of the Qara Qoyunlu (Black sheep) to seize Azarbaijan. Qara Yosuf's son Jahanshah was slain by Uzun Hasan (long Hasan, who was called by reason of his height), the chief of the rival Turcoman tribe of the Aq-Qoyyunlu (white sheep). Uzun Hasan and his successors were the masters of Iran until the rise of the Safavids. [24]

In 1501, Shah Ismail founded the Safavid dynasty who established the Twelver Shi' $i$ Islam as the official state religion. Initially, Turks who were staunch Sunnis tried to persecute the Shi'is in their realm, Isma'il was able to get widespread support for the Shi'i cause in Persia, and, in due course, a large majority of the inhabitants adopted Shi'ism and accepted Isma'il as their sovereign. In his own person he comprehended the qualities of a spiritual leader, a military commander, and a legislative reformer aware of the economic needs of his followers. Western sources describe Isma'il as a new prophet and provide us with evidence of the Mahdist and reforming aspect of his mission as well of the fanaticism of his 
followers, whose relationship to their leader was of the peculiar military-religious type. The historical achievement of the Safavids was to establish a strong, enduring state in Iran after centuries of foreign rule and a lengthy period of political fragmentation. [25] Religion constituted one of the strongest unifying forces in the early Safavid era. Under Isma'il Persia emerged as a nation once again.

Isma'il merged the ideas of divine justice and worldly kingship, employing the idioms of the Muslim Messiah to convey the promise of paradise on earth. Moreover, the shah did not wear the titles solely rhetorically, but exercised the functions from messiah-king. In his role of divinely just ruler, the shah shared war booty with his Qizilbash disciples and divided the conquered territories into appanages, which, as the governors and tutors of Safavid princes, his champions administered. The Venetian diplomat and eyewitness Francesco Sanuto related that Shah Isma'il's generous bestowals confirmed his image of God-on-earth for subject populaces. Although some of Muhammad's decedents (sayyids) were awarded privileges, including stipends and immunities from taxes, they were not only the group given economic relief or aid. A kind of social welfare was instituted under which craftsmen and merchants were exempted from supra-Islamic commercial taxes, and soup kitchens were set up for the poor and needy. Not surprisingly, during his reign Isma'il treasuries were often empty.

The "Shi'ification" and "Iranization" of the Safavid Empire over a period of a hundred years prepared the landscape of his newly conquered empire, and invited Arab Shi'i (Imami) scholars to emigrate to the Safavid domains from the Ottoman territories, which spanned greater Syria and included modern Lebanon, but many subjects, disapproving of his messianic claims, refused his patronage. The centurylong Ottoman strongly demarcated in the regions rivalries today. The developments in religious identification checked the fluidity the Irano-Turkish world stretching from Central Asia to the Balkans had known. The permanence of the shifts was not yet evident in the sixteenth century, but the impact of ideological change was soon experienced. On both Ottoman and Safavid sides, confessional ambiguities between Sunni and Shi'i that had characterized religious identities before the sixteenth century receded and were overtaken by the elaboration of increasingly inflexible sectarian positions.

Whether Isma'il was God or the messiah, he was a tough act for his son Tahmasp (r.1524-76) to follow when he died in 1524. Shah Tahmasp's account, or Tazkire, of his reign and character provides us with a fascinating narrative of the processes of conversion to Shi'ism that the Safavid realm underwent in the two subsequent centuries. In his memoir, Tahmasp rejected his fathers claim to be Messiah/God; instead, Tahmasp was the mystic lover of Ali and the Shi' $i$ monarch who abided by 
the Shar'iah(divine law). It is significant that Tahmasp took it upon himself to give this account of his father and himself; undoubtedly he wanted to ensure that future generations would rely on his won version of their two reigns rather than on contemporaneous or future court historians' impressions.He was steeped in the spirit of his preceptors and advisors; thus, like his father, he inaugurated his reign along the lines of Qizilbash teaching and then renewed, in a minor key, the experiment of transition to the traditional reform of Twelver Shi' ism. He continued the anti-Ottoman policy, and it was precisely during the least Twelver phase of his reign-and perhaps not altogether by chance-that the religious aspect of Iran seems to have undergone an effortless change, with the result that Shi'ism acquired a greater degree of homogeneity. The modern originality has its roots here, and in this sense Tahmasp can serve as a symbol; after a beginning marked by his Qizilbash background he soon fell under the influence of Shi'i 'ulama, the first notable occasion being his contacts, during the 1530 s, with the sayyids of Uskuya near Tabriz. [26] However, he lost Kurdistan and Mesopotamia to the Ottoman Turks; he kept intact the main part of Persia. He was a great patron of art and calligraphy and encourages the carpet-weaving industry. It was his gallant effort to open the trade between England and Persia. When Tahmasp died in 1576, Iran fell into the hands of Isma'1 II, who was drunkard and a libertine. His brother succeeded him, Muhammad Khudabanda. His incapable approach, Turks and Ozbegs took advantage of the situation to occupy the north-eastern and northwestern Persia. Fortunately for Persia, the situation saved by his son 'Abbas, who by his capable efforts recaptured the territories which were occupied by Turks and Ozbegs. In 1598, he moved his court from Qazvin to Isfahan and constructed splendid buildings, making it one of the largest and finest cities of the world. $\mathrm{He}$ also changed the system of government from a theocracy to one of absolute government. [27]

With the death of Shah 'Abbas, his grandson Shah Safi succeeded him. His poor policy was disastrous for Persia, as he neglected the army in which Shah 'Abbas had taken great care and Shah's carelessness made a way for Turks who were able to regain Baghdad. When Shah died, his young son ascended the throne, he restored the army to its former position but his efforts did not reach to the conclusion because of his death. [28] After him Shah Sulaiman ascended the throne, but he was ignorant towards the affairs of the state, and soon became drunkard. He, worn out by his debaucheries, died in 1694. His successor Shah Sultan Hussain, did nothing knew to wards the state affairs. The attack by Sunni Afghan tribe of Ghilzais invaded Persia from the east. Though outnumbered they defeated the royal forces and Tahmasp Mirza, the third son of Shah, escaped in order to raise a relieving force. Tahmasp, after wandering in Mazandaran with a handful of men, sought with Fath 'Ali Khan Qajar in the latter's tribal area of 
Astarabad. While there, he met a person, Nadir Quli Beg who supported him. An intense rivalry developed between Fath 'Ali khan and Nadir Quli Beg, which was ended only, when Tahmasp find that the Qajar chief was trying to execute him. [29] Tahmasp foolishly attacked the Turks and in return he was heavily defeated, loosing all the territory that Nadir had regained. Nadir deposed Tahmasp and placed the latter's infant son 'Abbas on the throne. In 1733, Nadir attacked the Turks and captured Baghdad; he forced the Russian to relinquish the territory which she has seized. He regained Erivan and Erzurum by defeated them. In 1736 Nadir, in front of the nation formally deposed Abbas III and assumed himself the title of Nadir Shah. His immediate step was march into India and heavily defeated the Mughal forces; he marched south and occupied Delhi. He obtained immense spoils. On his way back to Persia, he advanced towards northwards and subdued the Ozbegs of Bukhara and Khiva. But his death was followed by the usual scramble for the throne, Karim Khan Zand, of Luristan, emerged as the victor. He was one of the best and mildest rulers that Persia has ever had. He never claimed the title of Shah, being content of Vakil or Deputy. However his successors were always in continuous struggle for the throne, with the result they exhausted themselves and opened the way for the accession of Agha Muhammad Khan Qajar. [30] A new chapter in Persian history had begun.

\section{Acknowledgements}

The author would like to thank his supervisor Prof. G.N Khaki, University of Kashmir (Centre of Central Asian Studies), whose lectures and publications have inspired the preparation of this paper.

\section{REFERENCES}

1. Prof.Masudul Hasan, History of Islam, Vol I Adam Publishers, 1987, Delhi, p.99

2. Cyril Glasse, The Concise Encyclopedia of Islam, Stacey International, 1989, London, p. 407

3. Jurji Zaydan, History of Islamic Civilization, Kitab Bhavan, New Delhi,1987, p.37

4. Ibid, p.95

5. Prof.Masudul Hasan, History of Islam, Vol I Adam publishers, 1987, Delhi, p.110

6. Muhammad Husayn Haykal, Umar-al-Farooq, p.130

7. Muhammad Husayn Haykal, Umar-al-Farooq, p.130

8. R.N Frye, The Cambridge History of Iran, Cambridge University Press, Vol 4, 1975, pp. $46-47$

9. Ibid, p.4

10. E.G Brown, A Literary History of Arabs, Vol 1, Cambridge University Press, 1928, New York, p. 252 
11. Ibid, pp.254-55

12. Foltz, Richard, Spirituality in the land of the Noble: How Iran shaped the world Religion's, Oxford: One World Publications, 2004, pp.123-127

13. Sir Thomas Walker Arnold, The Preaching of Islam: a history of the propagation of the Muslim faith, pp.170-180

14. Richard Frye, The Heritage of Persia, p.243

15. Bernard Lewis has beautifully summed up: "Iran was indeed Islamized, but it was not Arabized. Persians remained Persians. And after an interval of silence, Iran reemerged as a separate, different and distinctive element within Islam, eventually adding a new element even to Islam itself. Culturally, politically, and most remarkable of all even religiously, the Iranian contribution to this new Islamic civilization is of immense importance. The work of Iranians can be seen in every field of cultural endeavor, including Arabic poetry, to which poets of Iranian origin composing their poems in Arabic made a very significant contribution. In a sense, Iranian Islam is a second advent of Islam itself, a new Islam sometimes referred to as Islam-i Ajam. It was this Persian Islam, rather than the original Arab Islam, that was brought to new areas and new peoples: to the Turks, first in Central Asia and then in the Middle East in the country which came to be called Turkey, and of course to India. The Ottoman Turks brought a form of Iranian civilization to the walls of Vienna..." E.G Brown, A Literary History of Persia, Vol I, Cambridge University Press, New York, 1928, p.480

16. Prof. Masadul Hasan, History of Islam, Adam Publishers, Delhi, p.30

17. Opp.cit., p.111

18. John A.Boyle, Persia, History and Heritage, Henry Melland Limited, London, P.33

19. M. Ravandi, "The Seljuq Court at Konya and the Persianization of Anatolian Cities”, in Mesogeios (Mediterranean Studies), (2005, pp.157-69

20. Opp.cit.,35

21. John A Boyle, Persia: History and Heritage, Henry Melland Limited,1987, London, p.35

22. Ibid, p.36

23. David J Roxburg, The Persian Album, 1400-1600: From Dispersal to Collection, Yale University Press, 2005, p.130

24. John A Boyle, Persia: History and Heritage, Henry Melland Limited, London, p.37

25. Peter Jackson and Laurence Lockhart, The Cambridge History of Persia, Cambridge University Press, Vol 6, 1986, p.189

26. Ibid, p.642

27. Opp.cit., pp.30-40

28. Ibid, p.42

29. John A Boyle, Persia: History and Heritage, Henry Melland Limited, London, 1978, p.42

30. Ibid, p.43 


\title{
Summary
}

\section{Expansion and Consolidation of Islam in Iran to the End of Qajar Period}

\author{
AshaqHussain, \\ University of Kashmir, India \\ G.N Khaki \\ University of Kashmir, India
}

Under Islam, for the first time since the Achaemenids, all Iranians including those of Central Asia and on the frontiers of India became united under one rule. Islam was rescued from a narrow Bedouin outlook and Bedouin mores primarily by the Iranians, who showed that Islam, both as a religion and, primarily, as a culture, need not be bound solely to the Arabic language and Arab norms of behavior. Instead Islam was to become a universal religion and culture open to all people. This was a fundamental contribution of the Iranians to Islam, although all Iranians had become Muslims by the time of the creation of Saljuq Empire. So, Iran in a sense provided the history, albeit an epic, of pre-Islamic times for Islam. After all, the Arabs conquered the entire Sasanian Empire, where they found fullscale, imperial models for the management of the new Caliphate, whereas only provinces of the Byzantine Empire were overrun by the Arabs. The present paper is an attempt to give reader a detailed introduction, emergence and spread of Islam in Iran. It is in this context the present paper has been analyzed.

Keywords : Islam, Achaemenids, Bedouin, Central Asia, Iran 